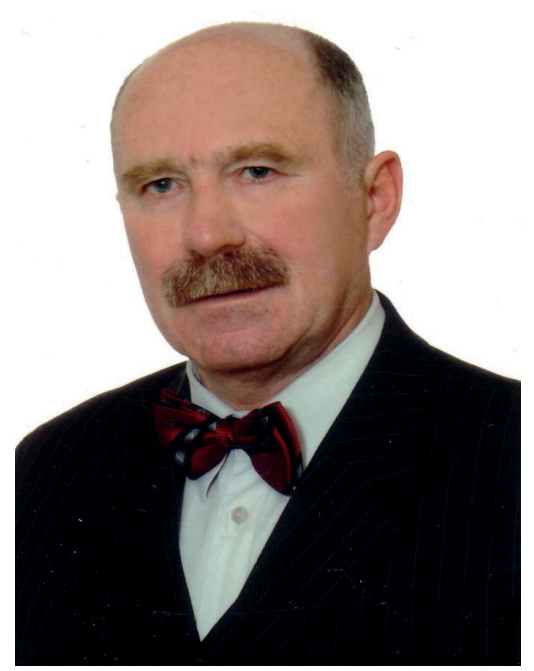

\title{
ACTIVITIES IN SUPPORT OF PSYCHOPHYSICAL FITNESS AND HEALTH PROMOTION OF MILITARY PILOTS - PERSONAL REFLECTIONS
}

Krzysztof S. KLUKOWSKI

Source of support: Own sources

Author's address: K. Klukowski, Warsaw, Poland, e-mail:kklukowski@wp.pl

Abstract: The author presents selected fragments of his research activity at the Military Institute of Aviation Medicine in Warsaw in the years 1971-2002. The author's career in aviation medicine began in the Department of Aviation Pathophysiology in the Laboratory of Flying Personnel Exercise Stress Tests with the position of Assistant Professor, then the Head of the Laboratory, next the Head of the Biological Renewal Team, then the Deputy Commandant of the Institute for Scientific Research, ending with the position of the Commandant of the Institute. The article presents in a condensed way the author's activity in the field of psychophysical fitness and health promotion, especially of military pilots. The main scientific interests of the researcher concerned the fitness preparation of pilots, including physical flight factors tolerance, changes in exercise capacity over age, methodology of exercise stress tests and setting standards of physical fitness, as well as health promotion with biological regeneration elements. Many new solutions, e.g. exercise stress tests in high altitude hypoxia, have been used in competitive sports.

Keywords: methods of diagnosing aptitude and physical fitness of pilots, fitness standards, health promotion in the Polish Air Force 
K.S. Klukowski - Activities in support...

\section{THE BEGINNINGS OF WORK AT MILITARY INSTITUTE OF AVIATION MEDICINE (MIAM)}

After graduating from the Medical Faculty of the Military Medical Academy (WAM) in Łódź (1969) and completing a postgraduate internship at the CSK CKP WAM and WIML in Warsaw (1969-1971), I was sent, by way of distinction (third place at WAM), to work at the Military Institute of Aviation Medicine in Warsaw. The initiator of my work at the Institute was the then Commandant col. Zbigniew Jethon, MD, PhD, Associate Professor, who in 1968, when I was still a student of the fifth year, encouraged me to come to work at WIML. The commander knew about my additional studies at the University of Physical Education in Warsaw, and the condition for referral to the Institute was a high position after graduation. I knew that ass. prof. Zbigniew Jethon is a recognized aviation physician and experimental physiologist, as well as an authority in the field of physical preparation of pilots. That is why I was interested in the possibility of working at the Institute. However, the decision about my employment with WIML was made during a face-to-face interview (October 1971) by the new commander prof. Stanisław Barański, MD, PhD, Associate Professor, and the Head of Air Force Health Services col. Leszek Szymańczyk, MD. The fact that I graduated from the University of Physical Education in Warsaw, as well as close cooperation of WIML with Military Fitness Training Centers for flying personnel in Mrągowo and Zakopane, were the determinants of my new job, or military service in fact. Col. Zbigniew Sarol, MD, (Head of the Department of Aviation Pathophysiology), who was called to the commandant's office, convinced me of a better start in the experimental unit of the Institute and resignation from the idea of being a cardiologist in the clinical unit in the future. I took my first medical steps as a beginner physiologist in the Physical Performance Laboratory of the Department of Aviation Pathophysiology, under the supervision of the sports doctor and the exercise stress physiologist col. Zbigniew Dziuk, MD, with considerable help in the scope of exercise stress tests provided by major Bronisław Turski, MD, one of the best basketball players of the Military Medical Academy team. One of the employees of the Laboratory was also major Henryk Sulajnis, MA, a former representative of Poland in a modern pentathlon, which resulted in many years of cooperation and scientific work in the field of performance and fitness of flying personnel. Their pioneering work was supervised by a long-time collaborator of prof. Z. Jethon and a continuator of joint research - col. Zbigniew Sarol, MD, Associate Professor, Head of the Department of Aviation Pathophysiology.
In the years 1976-1978 I took an active part in preliminary preparations, qualification tests and special trainings of Polish candidates for cosmonauts. During this period, I held consultations at the Yuri Gagarin Cosmonaut Training Center in Star City and at the Institute of Biological and Medical Problems in Moscow, where I got acquainted with the methodology of qualification and selection tests for the purposes of cosmic medicine.

\section{FURTHER CAREER DEVELOPMENT}

In 1977, a student of prof. Julian Walawski - prof. Lech Markiewicz, MD, became the Head of the Department of Pathophysiology, who gave a new impetus to scientific work and actively supported future postdoctoral students (Mieczysław Wojtkowiak, Józef Domaszuk, Eugeniusz Sokołowski, Krzysztof Klukowski, Lucjan Golec, Bronisław Turski, Marek Kłossowski). All the aforementioned researchers, regardless of aviation medicine issues, were involved in the extreme environmental medicine and physical effort. This resulted in numerous joint works on the borderline between sports medicine, high altitude hypoxia physiology, hypergravity physiology, etc. At the initiative of prof. L. Markiewicz, I was appointed the secretary of the Commission for Work Physiology and Physical Activity of the Committee on Physiological Sciences of the Polish Academy of Sciences, bringing together outstanding researchers of applied physiology in Poland (prof. prof. Bolesław Gwoźdź, Zbigniew Jethon, Adam Klimek, Stanisław Kozłowski, Ryszard Kubica, Eugeniusz Miętkiewski, Józef Sysa). In addition to my previous academic achievements so far, I prepared a habilitation dissertation. It concerned changes in physical fitness with age and their connection with risk factors of civilization diseases of military pilots, which I defended in 1984 before the Scientific Council of WIML.

As part of my further scientific and professional advancement, I became the Head of the WIML Biological Renewal Team (1985-1994), Deputy Scientific Commandant (1995-1996) and the Commandant of the Institute (1997-2002). In the years 1993-1994, I was also appointed Chairman of the Scientific Council of WIML. In 1994 I was promoted to the position of a titular professor. I received the title, wearing the gala uniform of the air forces captain, from President Lech Wałesa, thanking the President of Poland on behalf of newly appointed scientists and artists (Jerzy Stuhr, among others).

Within the framework of cooperation with col. Roman Maciej Kalina, PhD, and It. col. Marek 
Kłossowski, PhD, in 1995 we established, on the basis of WIML, the Physical Education in the Army Section of the Polish Scientific Society of Physical Education (Polskie Towarzystwo Naukowe Kultury Fizycznej - PTNKF). I am elected first President of the section (1995-2003), It. col. M. Kłossoswki, PhD - Deputy President and col. R. Kalina, PhD - Secretary. The great advocate of the establishment of the military section was the President of the PTNKF prof. Tadeusz Ulatowski, PhD, great authority in the theory of physical education and sports in Poland, long-time rector of the Józef Piłsudski University of Physical Education in Warsaw. Thus, WIML became a center of innovative solutions in the field of physical education of uniformed services (the Police, border security forces, fire brigades, prison service). We organized numerous conferences in various training centers of defense formations, each time publishing post-conference monographs of informational and implementation nature.

Within the framework of cooperation between WIML and the Main Center for Aviation and Medical Research of the Polish Aeroclub (Główny Ośrodek Badań Lotniczo-Lekarskich Aeroklubu Polskiego - GOBLL-AP) in Wrocław, in cooperation with the director Janusz Marek, MD, in the years 1997-2001 we operated in the Physiological and Medical Commission of the International Federation of Aviation (CIMP-FAI). At the organized training conferences (Join-Meeting) concerning aviation sports, we presented the issues of injuries in parachute jumps as well as cervical spine overloads in air acrobatics. We implemented the latter topic together with col. Jan Talar, MD, (from 23 WSK in Bydgoszcz) $[47,48,49]$.

\section{PUBLICATIONS ON THE PSYCHOPHYSICAL FITNESS OF PILOTS}

I owe my first scientific publications to the inspiration and help of It. col. Zbigniew Dziuk, PhD, who offered me co-authorship in many works, at the same time exercising substantive supervision over my first works. Due to the cooperation between MIAM and Military Training and Fitness Centers (MTFC), active recreation of pilots had always been a great topic, in the context of military service burdens and in comparison with other types of military troops [5]. In 1974 I defended my doctoral thesis on the tolerance of flightenvironment factors and physical fitness of overweight pilots. The thesis was promoted by the commandant of the Institute, col. Stanisław Barański, MD, PhD, Associate Professor, a renowned scientist and specialist in aviation and space medicine. He was also a great advocate of conducting scientific work on the basis of WOSzK and introducing elements of biological regeneration to the training program for flying personnel. At the commanding officer's initiative, I was actively involved in the preparation of doctoral theses of WOSZK medical and instructor staff (It. col. Aleksander Krzyściak, MD, cpt. Kazimierz Czuriszkiewicz, MA, cpt. Jan Marks, MA, - from WOSZKZakopane and It. col. Marian Doraczyński, MD, from WOSzK-Mrągowo). Currently, my role in the promotion of successful doctorates at WIML and AWF (Cracow, Warsaw) would be described as an auxiliary promoter.

\section{MILITARY FITNESS TRAINING CENTRES}

In the air force, a lot of attention is paid in preparation of a professional pilot to the issues of physical performance and fitness, as well as to the issues of active recreation. This stems from the specificity of work (impact of physical factors of flight on the body, requirements of high altitude rescue, etc.), as well as the awareness of the need to maintain a high standard of health by pilots $[18,27,39,44,50]$. In this sense, fitness and performance indicators of flying personnel can be considered as positive measures of health $[22,40,41]$. Many MIAM studies have shown that an important achievement of all activities aimed at maintaining a good standard of health is the annual stay of pilots at military training and fitness centers (MTFC-Mrągowo and MTFC-Zakopane). They are used to supplement deficiencies in fitness preparation, to relieve adverse emotional tensions, to regulate calorific surpluses and to implement new forms of active recreation $[27,39,44,50]$. Substantive supervision over the above projects was performed by MIAM, through appointment of MTFC consultants team. It consisted of: a physical education specialist (Henryk Sulajnis, MA), a sports physician and physiologist (Krzysztof Klukowski, PhD), an aviation psychologist (Jan Terelak, PhD) and a nutrition specialist (Mieczysław Pędziwiatr, PhD). Initially, the team was headed by col. Henryk Sulajnis, MA, (19741979), and I was appointed to this position in 1980 (even before obtaining habilitation). It is worth mentioning that the widely understood physical culture would not be fully effective in preventing civilization diseases of the aviation personnel if it was not included in the comprehensive system of interactions of health education provided by specialists from MIAM. This includes projects aimed at rational nutrition, appropriate psycho- 
physical regeneration, systematic physical activity, combating unfavorable addictions and periodic assessment of health status (performance and fitness tests, ECG exercise tests).

Military pilots are more prone to cervical and lumbar spine pain than other professional populations of healthy men [49]. Therefore, regardless of institutional activities (stay at MTFC, MIAM), pilots should regularly use various forms of biological regeneration on their own, which I opted for in relevant publications [25]. I believed that biological regeneration of pilots is not a fashion, but a necessity, integrated into their active and healthy lifestyle.

In the scope of creating health promotion programs and implementing health training for military pilots based on WOSzK, together with It. col. Krzysztof Mazurek, MD, we established a longterm and close cooperation with Henryk Kuński, $M D$, Head of the Sports Medicine Laboratory of the Medical Academy in Łódź and the Provincial Sports and Medical Clinic, an outstanding expert in the issues of adult health training in Poland. It was also connected with many years of scientific and social ties with the team of doctors of the Laboratory (later professors: Wojciech Drygas, Anna Jegier, Tomasz Kostka). As a result of the cooperation, many elements of health training and practical experience of the Łódź team were transferred to military aviation [41]. Thanks to the initiative of col. K. Mazurek, MD, who was the President of the Main Military Aviation and Medical Commission at WIML, a system of exchange of medical information between WIML and WOSzK doctors was implemented. They were sending a list of the aviation staff, future participants of the training and fitness camp to the Chairman of the Main Military Aviation and Medical Commission. Preventive recommendations were made based on the pilot health indicators obtained during the last Main Military Aviation and Medical Commission examination

On this basis, the participants of the WOSzK camp used: a low cholesterol diet, appropriately selected sets of physical exercises and physiotherapeutic treatment. The final results of medical examinations and performance and fitness tests were forwarded back to the GWKLL computer database. On the basis of experience in special trainings conducted with pilots in WOSzK (special aviation gymnastic devices, ground catapult, low pressure chambers, etc.), a program of special trainings for Polish candidates for cosmonauts was developed at WIML in 1976 (col. ass. prof. Z. Sarol, col., Henryk Sulajnis, PhD). Psychological tests were also an important element of examinations as well as the choice and psychological selection of candidates for cosmonauts [51]. My task was to provide supervision and medical care over the classes conducted in WOSzK Mrągowo and WOSzK-Zakopane. During the two-week camp in Mrągowo I had 14 pilots of supersonic planes under my care. Basing on selection tests (psychological tests conducted by col. ass. prof. Romuald Błoszczyński) and earlier tests at WIML, 8 pilots were selected for further recruitment. At WOSZK-Mrągowo, all pilots were catapulted on the UTKZ ground device as part of their assessment of their task stress tolerance. I have also undergone this procedure with a view to better understanding how impact acceleration affects the pilot's organism. My feelings - after the shooting I was a bit stunned on the verge of unconsciousness, then for a few days I felt burning around my back, as if burnt by a hot iron. The next 14-day camp took place in WOSzK-Zakopane, and two new participants were co-opted to the group of 8 pilots, including the most experienced pilot It. col. Zenon Jankowski. It turned out that despite his training backlog he did not have any fitness problems with reaching subsequent peaks in the Tatra Mountains.

\section{TESTING OF NATIONAL TEAM ATHLETES IN A LOW-PRESSURE CHAMBER}

Under hypobaric hypoxia (simulated altitude, hypoxia in the low-pressure chamber), physical exercise is associated with incomplete coverage of oxygen demand of working muscles and increased share of anaerobic metabolism. Similar processes are observed in combat sports. For example, in box there are loads in excess of $65 \%$ of the maximum oxygen uptake (VO2max - physical fitness indicator) and heart rate above 165/ min. In boxing fights, heartbeats are close to individual maximum values. It was assumed (team coach mgr Andrzej Gmitruk, sports physician Lech Święcicki, sports psychologist dr. Jan Terelak) that submaximal exercise tests (heart frequency up to $165 / \mathrm{min}$ ), performed under hypoxia conditions (simulated altitude of $3,000 \mathrm{~m}$ a.s.l.) could be helpful in assessing the state of training of the boxing team. The study covered 18 boxers of the Olympic team preparing for the Summer Olympic Games in Seoul. Among the athletes undergoing tests were Dariusz Michalczewski and Andrzej Gołota, then still promising young athletes, and later world-class professional boxers. The load pattern on the bike ergometer corresponded to a threeround ( 3 minutes each) boxing fight. In the heart 
rate-load biofeedback, the FIZJOTEST-801 device was used, the first version of which was tested in Mirosław Hermaszewski's flight in the "HEALTH" experiment (pre-flight and post-flight tests) [32]. The boxers were tested in the Low Pressure Chamber at the Military Institute of Aviation Medicine in the Department of Aviation Pathophysiology $[24,46]$. It was shown that decreases in average power and volume of work in hypoxia conditions are dependent on the state of training, because boxers with a higher degree of training did more work, had lower decreases in power in individual rounds and tolerated higher values of lactic acid concentration (they could lead to a more intensive level of fight). This helped the coach to set the intensity of the boxing fight in each round individually for each competitor. Andrzej Gołota returned from Seoul with the bronze Olympic medal.

\section{SUMMARY OF PUBLICATION ACTIVITIES}

The basic directions of my research interests related to the issues of physical culture and the evaluation of pilots' exercise capacity, presented in numerous publications, were:

- the problem of performance preparation of pilots, including physical flight factors tolerance $[2,3,12,16,23,33,34,36]$;

- the role of MTFC in improvement of psychophysical condition and biological regeneration of pilots $[11,18,25,27,43,44]$;

- changes in exercise capacity with age and its impact on work ability $[17,20,21,42]$;

- methodology for exercise stress examinations related to submaximal tests used in qualification and periodic health examinations of pilots $[9,13,28,37,38]$;

- flying personnel performance and fitness standards $[6,10,19,26]$;

- biological regeneration of flying personnel $[4,5,14,29,39]$;

- selected issues of physical education, sports medicine and aviation medicine $[7,14,30,35,45]$;

- physical activity in health promotion $[22,30,40,41]$;

- physical preparation of candidates for cosmonauts $[1,15,31,32]$.

\section{FINAL REMARKS}

Being unable to agree with the then command of the Polish Flight-and-Air Defense Forces on the restructuring of WIML (the dispute concerned the abandonment of scientific activity in favor of maintaining financing from the clinical hospital budg- et), in 2003 I left the reserve and took up employment as an academic teacher at the Józef Piłsudski University of Physical Education in Warsaw. I was offered a job at the University of Physical Education by the Rector Elect, Andrzej Wit, MD, PhD, Associate Professor, at the instigation of col. prof. Roman M. Kalina, PhD. Col. Krzysztof Mazurek, MD, also took up, with my intercession, work at the University of Physical Education, for whom no job was found at WIML after previous transfer to the reserve. Initially, I worked as a full professor at the Institute of Tourism and Recreation at the Faculty of Physical Education, then I was appointed VicePresident for Promotion and Sport (2003-2005). In the years 2005-2006 I became the head of the Department of Physiology and Biochemistry at the Faculty of Physical Education, and then I changed the faculty and from 2006 to 2012 I was the Head of the Department of Physiotherapy at the Faculty of Rehabilitation.

The scientific events worth remembering include my speech including the Allard Lecture in 2005 in Warsaw at the International Congress of Aviation and Space Medicine. The lecture concerned the issues of tolerance limits of the human body in extreme conditions of hypoxia, gravity and interplanetary flights. I consulted the content of this lecture with prof. Andrzej Trzebski, MD, Dean of the Division V: Medical Sciences of the Polish Academy of Sciences. The presentation recalled, among others, the contribution of great Poles to world science and the records of Polish aviators (including sports ones). The aforementioned lecture is treated in the world of aviation medicine as the highest honorary distinction for the aviation doctor of a given country, awarded with a special medal.

In 1987 I was appointed a member of the Physical Education Science Committee of the Polish Academy of Sciences, and after the reorganization of the committees I was elected Vice-Chairman of the Committee on Rehabilitation, Physical Education and Social Integration of the Polish Academy of Sciences (2009-2015), and since 2016 I have been the Chairman. Also in the years 20032005 I was the President of the Polish Society of Sports Medicine (since 2016 I have been the Honorary Member).

Taking into account my entire activity in the field of physical education, sports medicine and rehabilitation, in 2013 the senate of the University School of Physical Education in Wrocław awarded me the title of doctor honoris causa. In the conclusion of the eulogy, prof. Marek Woźniewski, PhD, said, underlining my achievements: "...in recogni- 
tion of the merits in the development of aviation medicine and sports medicine, as well as medical rehabilitation and the exercise stress physiology, and in particular the promotion and worthy representation of the physical education sciences and consistent care for their position in the scientific community, please accept the highest academic dignity awarded by the University School of Physical Education in Wrocław...".
To conclude my reflections, by necessity highly reduced, I certainly did not manage to mention all the people to whom I owe the opportunity to find out the scientific truth and fascination with aviation and space medicine. However, I certainly owe my most important achievements to my work at the Military Institute of Aviation Medicine and the possibility of meeting great people from military and civil aviation, as well as outstanding physical culture figures in Poland.

\section{AUTHORS' DECLARATION:}

Study Design: Krzysztof S. Klukowski; Data Collection: Krzysztof S. Klukowski; Manuscript Preparation: Krzysztof S. Klukowski. The Author declares that there is no conflict of interest.

\section{REFERENCES}

1. Barański S, Gierowski Z, Klukowski K. Wstępna selekcja kandydatów do lotów kosmicznych. Postępy Astronautyki. 1981; 14(1/2):49-56.

2. Barański S, Klukowski K. Wydolność i sprawność fizyczna jednym z warunków bezpieczeństwa lotów. Medycyna Lotnicza. 1982; 2(75):1-9.

3. Domaszuk J, Klukowski K. Wydolność fizyczna pilota a tolerancja czynników lotu. Przegląd WL i WOPK. 1997; 9:45-47.

4. Doraczyński M, Klukowski K. Profilaktyka urazów sportowych personelu latającego. Przegląd WL i WOPK. 1980; 4:54 AM-55.

5. Dziuk Z, Klukowski K. Sztuka wypoczynku. Wojsko Ludowe. 1973; 8(279):79.

6. Dziuk Z, Klukowski K. Normy wydolności (PWC170) pilotów. Lekarz Wojskowy. 1977; 11:722-724.

7. Kalina RM, Klukowski K, Czarniecki A. Dwubój obronny jako test specjalnej sprawności fizycznej pilotów wojskowych. Pol Przeg Med. Lot. 2000; 2:123-134.

8. Klukowski K. Sprawność specjalna pilota. Przegląd WL i WOPK. 1974; 12:38 PM-34.

9. Klukowski K, Sulajnis H. Zastosowanie próby stopnia do oceny wydolności fizycznej (pułapu tlenowego). Przegląd WL i WOPK. 1976; 11:61-64.

10. Klukowski K, Dziuk Z. Normy wydolności fizycznej pilotów. Kultura Fizyczna. 1976; 11:495.

11. Klukowski K, Doraczyński M. Wpływ treningu fizycznego w WOSZK Mrągowo na wydolność fizyczną pilotów. Medycyna Lotnicza. 1978; 61:55-58.

12. Klukowski K, Kłossowski M, Domaszuk J, Dziuk Z. Badania współzależności między zdolnością wysiłkową a tolerancją przyspieszeń +Gz. Medycyna. Lotnicza. 1979; 63:15-18.

13. Klukowski K, Kłossowski M, Dziuk Z. Metodyka doboru obciążeń wysiłkowych w badaniach rutynowych wydolności fizycznej. Kultura Fizyczna. 1980; 2:15 AM-16.

14. Klukowski K, Kłossowski M. Współpraca lekarza z instruktorem WF w jednostce lotniczej. Przegląd WL i WOPK. 1980; 3:50 AM-51.

15. Klukowski K, Markiewicz L. Wybrane aspekty treningu fizycznego kosmonautów. Series: Monografie AWF Poznań. 1980; 143:39-47.

16. Klukowski K. Znaczenie wskaźników sprawności fizycznej i zdolności wysiłkowej w adaptacji zawodowej pilotów. Series: Monografie AWF Poznań. 1980; 191:73-78. 
17. Klukowski K, Dziuk Z. Zdolność wysiłkowa pilota. Przegląd WL i WOPK. 1981; 7-8:66-71.

18. Klukowski K. Ocena efektywności turnusów specjalnych dla pilotów z nadwagą. Medycyna Lotnicza. 1982; 1(74):15-21.

19. Klukowski K, Markiewicz L. Średnie wartości maksymalnego poboru tlenu (VO2max) u zdrowych mężczyzn.. Acta Physiol Pol. 1983; 34(2) supl. 25:147-157.

20. Klukowski K, Sulajnis H. Zdolność wysiłkowa pilotów a wiek. Kultura Fizyczna. 1983; 5-6:16-19.

21. Klukowski K. Zmiany zdolności wysiłkowej z wiekiem i ocena stanu zdrowia pilotów. Medycyna Lotnicza. 1983; 3(80):1-10.

22. Klukowski K. Wydolność fizyczna a stan zdrowia pilotów w świetle obecnego systemu kultury fizycznej Wojsk Lotniczych. IV Konferencja naukowa - Wychowanie zdrowotne w wojsku. Wyd. MON. 1987; 228-234.

23. Klukowski K, Kowalski W. Wymogi kondycyjne i higieniczne w poprawie tolerancji przyspieszeń. Medycyna Lotnicza. 1989; 1(102):19-29.

24. Klukowski K, Święcicki L, Markiewicz L, Gembicka D, Pińkowski J. Wpływ umiarkowanej hipoksji na zdolność wysiłkową sportowców w zależności od stanu wytrenowania. Series: monografie AWF Poznań. 1990; 274:55-66.

25. Klukowski K. Odnowa biologiczna pilotów moda czy konieczność? Przegląd WL i OPK. 1990; 5:47 AM-51.

26. Klukowski K, Kłossowski M, Marks J. Propozycja testów sprawności fizycznej dla wojskowego personelu latającego. Medycyna Lotnicza. 1992; 1-2(114-115): 44-48.

27. Klukowski K. Pilot wojskowy nie może obyć się bez WOSZK. Przegląd WL i OPK. 1992; 11:33 AM-35.

28. Klukowski K, Kłossowski M. Metodyka badań i ocena zdolności wysiłkowej personelu latającego. Medycyna Lotnicza. 1992; 3-4(116-117):6-16.

29. Klukowski K, Markiewcz L. Wpływ metod aktywujących restytucję powysiłkową na wydolność fizyczną. Medycyna Lotnicza. 1992; 3-4:116-117.

30. Klukowski K, Kłossowski M, Możański G. Kultura fizyczna w promocji zdrowia pilotów wojskowych. Przegląd WL i OP. 1993; 9:87-91.

31. Klukowski K. Reminiscencje związane z 30-leciem lotu pierwszego Polaka w kosmos. Pol Przeg Med. Lot. 2008; 2(14):125-133.

32. Klukowski KS, Skibniewski FW. A historical look at the biomedical tests conducted by cosmonauts during the orbital flight Soyuz 30/Salyut 6. Pol J Aviat Med Psychol. 2013; 19(3):17-22.

33. Klukowski KS., Mazurek KL. Medycyna lotnicza - wpływ przyspieszeń na układ sercowo-naczyniowy. In: Braksator W., Mamcarz A. (scientific ed.) Kardiologia Sportowa w praktyce klinicznej. Wyd. Lek. PZWL, 2016; 515-526.

34. Kłossowski M, Klukowski K, Jonak R, Paszkiewicz K. Wydolność aerobowa pilotów odrzutowych. Pol Przeg Med. Lot. 2000; 3(6):211-222.

35. Kuński H, Klukowski K. Wspólne drogi kształtowania związków medycyny lotniczej i sportowej w Polsce w latach 1918-1039. Pol Przeg Med. Lot. 2004; 1(10):65-75.

36. Markiewicz L, Klukowski K, Kłossowski M. Wpływ ćwiczeń na lotniczych przyrządach specjalnych na organizm. Przegląd WL i WOPK. 1981; 7-8:56-58.

37. Markiewicz L, Klukowski K, Kuska K, Mazurek K. Propozycja doboru testów wysiłkowych stosowanych w badaniach przeglądowych personelu latającego. Med. Lotnicza. 1985; 2(87):37-42.

38. Mazurek K, Klukowski K, Kuska K. Ocena układu krążenia w orzecznictwie lotniczo-lekarskim. Medycyna Lotnicza. 1983; 1(78):13-20.

39. Mazurek K, Kuński H, Klukowski K, Stępień A. Rola Ośrodków Szkoleniowo-Kondycyjnych (WOSzK) w kinezyterapii i kinezyprofilaktyce personelu latającego, In: Rutkowska E. (ed.) Aktywność fizyczna w pielęgnowaniu zdrowia i terapii chorób. Akademia Medyczna, Lublin. 1998; 30-32.

40. Mazurek K, Modrzewski A, Marek J, Klukowski K. Prevention of health in military, civil and sports pilots. FAI/CIMP Join Meeting, Helsinki-Stockholm. 29-30.05.1998.

41. Mazurek K, Kuński H, Klukowski K. Zdrowie pozytywne a aktywność fizyczna pilotów. In: Mazurek K. (ed.) Epidemiologia i profilaktyka chorób personelu lotniczego. Postępy Med. Lot. 2001; 194:25-34.

42. Sarol Z, Błaszczakiewicz M, Dziuk Z, Sulajnis H, Klukowski K. Wydolność i sprawność fizyczna pilotów po 40 roku życia. Medycyna Lotnicza. 1974; 45:25-41.

43. Sarol Z, Kłossowski M, Dziuk Z, Klukowski K. Tolerancja wysiłkowa układu krążenia u pilotów w piątej dekadzie życia po trzytygodniowym treningu. Series: Monografie AWF Poznań. 1978; 115:51-57.

44. Sarol Z, Klukowski K, Kłossowski M. Rola Wojskowych Ośrodków Szkoleniowo-Kondycyjnych w regeneracji sił psychofizycznych pilotów. Medycyna Lotnicza. 1979; 64-65:30-33. 
45. Sulajnis H, Klukowski K, Kłossowski M. Cele i zadania wychowania fizycznego personelu latającego. Przegląd WL i WOPK. 1978; 1:58 AM-61.

46. Święcicki L, Klukowski K, Kłossowski M, Lewicki R. Ocena stanu wytrenowania bokserów w systemie przygotowań przedolimpijskich. Trening. 2004; 2(22):6-22.

47. Talar J, Kłossowski M, Klukowski K, Tomaszewski W. The assessment of sports pilots’ spinal mobility after aerobatics. Med. Sport. 1996; 4(57):16-18.

48. Talar J, Klukowski K, Kłossowski M, Marek J, Gebuza A. La Movilidat vertebral en relacion con el vuelo acrobatico y la fisioterapia. Medicina Aerospacial y Ambiental. 1997; 2(1):3-7.

49. Talar J, Mazurek K, Klukowski K, Kwasucki J, Marek J, Stępień A. Review of the vertebral column pain problems in polish pilots. RTO Technical report 4 „Technology Watch on Spinal Injury to Repeated Exposures to Susstainned Acceleration. Chapter. 1998; 9:36 AM-39.

50. Terelak J, Sarol Z, Sulajnis H. Ocena warunków podnoszenia kondycji psychofizycznej personelu latającego w WOSzK. Medycyna Lotnicza. 1976; 52:29-35.

51. Terelak J, Błoszczyński R. Problemy doboru i selekcji psychologicznej kosmonautów. Medycyna Lotnicza. 1978; 59:18-27.

Cite this article as: Klukowski K.S. Activities in Support of Psychophysical Fitness and Health Promotion of Military Pilots Personal Reflections. Pol J Aviat Med Bioeng Psychol 2017; 23(3-4): 24-31. DOI: 10.13174/pjambp.20.12.2018.05 